\title{
TEACHERS, STUDENTS AND EXTRACURRICULAR ACTIVITIES IN PRIMARY EDUCATION
}

\author{
M.A. Ankica Antovska, State University of Tetovo, Republic od Macedonia \\ E-mail: ane_prima@yahoo.com \\ Dr. Borče Kostov, Faculty of Philosophy, University St. Cyril and Methodius, Skopje, Republic of Macedonia \\ E-mail: borce.kostov@fzf.ukim.edu.mk
}

A R T I C L E I N F O

Original Article

Received: Ferburary, 20.2016.

Revised: April, 21.2016.

Accepted: April, 26.2016.

doi:10.5937/IJCRSEE1601049A

UDK

371.322.5-057.874(497.7)

379.8-057.874(497.7)

\section{Keywords:}

leisure time,

primary education,

teachers,

students,

school.

\begin{abstract}
A B S T R A C T
In the scientific public, since long ago, there has been an interest in studying leisure time. Leisure time is a central issue of modern civilization, integral part of the structure of modern society and a significant factor for a person's development. The goal of this research is to study the modern concept of and the benefits from the introduction of leisure (extracurricular) activities in the primary education process. Certain investigations show that teachers, through extracurricular activities, can have a significant role in building and improving the talents of students. From the answers received in the enquiry it can be seen that both teachers and students have different attitudes and interests regarding extracurricular activities.

The school has still the best position and the hope for developing students' skills for the wide world of extracurricular activities.
\end{abstract}

(C) 2016 IJCRSEE. All rights reserved.

\section{INTRODUCTION}

A few important points can be distinguished, which impose the need for scientific justification for investigation of leisure time. Firstly, scientific justification is reflected in the fact that the issue of leisure time hasn't been yet a subject of permanent and systematic pedagogical research. Secondly, leisure time as a field of modern pedagogical science is not treated enough from the aspect of all the technical, technological and material conditions. Furthermore, efforts ought to be made for students' education and training through leisure time (extracurricular) activities. A very important problem is that in the Republic of Macedonia there is no theoretically elaborated scientific paper in this field (Barakoska, 2005).

The need for investigating the problem of leisure time in general and for investigating students' free time in particular, gets special importance if it is viewed also from the aspect

Corresponding Author

Dr. Borče Kostov, Faculty of Philosophy, University St. Cyril and Methodius, Skopje, Republic of Macedonia E-mail: borce.kostov@fzf.ukim.edu.mk

\section{(c)}

This work is licensed under a Creative Commons Attribution 4.0 International license. The article is published with Open Access at www.ijcrsee.com of current problems of our society, defined as a society in transition.

That's why this subject of investigation has the intention and the goal of reaching to the children - the youngsters, and this way to act purposefully as much as it is beneficial, in order to have some positive repercussions - more specifically, in the part of everyday fulfillment of life in every time, s.c. free will for fulfilling leisure activities or the free time. This necessity is indicated also by some unacceptable acts and behaviours of young people in everyday life, i.e. young people are the hardest stricken category by the phenomenon's of social pathology, and for that reason they become addicted to modern vices like drugs, alcohol, influences of the political parties and so on, and in the process they may transform into deviant and delinquent persons. A large number of youngsters socialize with their alike, i.e. with those who have similar systems of values, orientations, economic status and interests (Marković, 1997). Instead of building themselves as successful persons, they set on the road to destruction.

Delinquency is more frequent where there are problems present in the family life, which is where the children are less connected with their family, since the parents "waste" themselves on daily basis for satisfying material needs of the family, thereby not finding enough time for proper socializing with their 
own children. The parents lose their sense for the developmental needs of their children who become more and more vulnerable because they are exposed to provocative kitsch, moral slime, profiteering competitions, recruitment by religious sects (Budimir-Ninković, 2008).

This description of the contemporary situation in the world is confirmed by the members of the new Roman club who, in their report on the dilemmas of the modern society, also indicate the "complex of problems" that trouble the people from all nations: unemployment, alienation of young people from their families, rejection of the traditional values, and other financial and economic anomalies (Plenković, J., and Zalokar, J. 2000).

German sociologist Ralph Dahrendorf, in his very interesting analysis of leisure time, comes to the conclusion that leisure time is a precondition for a person's freedom and selfdevelopment. According to him, leisure time becomes an essential factor for the individual by the very fact it eliminates the compulsion present in the production process during working hours and enables development of the individual. Therefrom it follows that development of a person's abilities and improvement of one's own qualities is a fundamental task in life. Becoming "improved" is a goal that has to be achieved through independent work over one's own self. For fulfilling that task, the person ought in the first place to get acquainted with himself/herself, and only then to start self-creation. Aristotle (Woodfin R., Groves, J., 2003) has said: "The hardest won victory is to defeat your own." When I say this, I want to stress that the issue here is not education, but self-education instead.

One very important name in the field of sociology is Joffre Dumazedier, who interprets leisure time as a "system of activities to whom the person surrends completely no matter whether he/she uses it for rest or recreation, or for developing his/her own free creative abilities, after being relieved from the own professional, family and social duties (Dumazedier, 1963).

He emphasizes the three main functions of leisure time: repose, entertainment and personal development, but here the issue arises on the classification of these three basic functions, particularly from the aspect of personal development. The third function may instigate in the person a free discipline because of the free development of the personality in both individual and social manners.

In example, the great Greek philosophers Plato and Aristotle (Corbett, E. P., 1984) didn't disparage playing, or considered it being useless activity. Plato points out that young people, through playing and musical education, become straight citizens who start building what was destructed by their predecessors. This way, Plato wants to stress the need of youngsters to play and to express their specific way of feeling satisfaction. On his part, Aristotle insists on connecting work with play, and points out the need for understanding contradictions between work and entertainment, where entertainment for the free citizens is a fundament of everything and is necessary for developing noble educational activities.

The big scope of extracurricular activities and their contents enable young people to acquire values and properties which may be of use in their lives. In the era of modern technology, education and research become necessary for being able to do the jobs properly. The human isn't able without knowing things to create, produce and make earning. That's why Ronald Burt deems the generations from 1960s onwards as thinking generations. Although the provision of extracurricular activities at school has a long tradition in some countries, it was only at the beginning of the millennium that the quality of education and extracurricular activities started to receive increased attention in educational policy and practice in Europe. In 2003, for example, the "all-day school" started to be promoted in Germany and the number of these schools was expanded across the nation. At the same time, "the integrated school day" with organized extracurricular activities as a part of school had just been introduced in Finland with the goal of decreasing the amount of time children spend unsupervised. A similar development can be identifi ed around this time in England, where "extended services" were provided, including extracurricular activities at schools, in an attempt to build cooperation between schools and families. In Switzerland there have been similar changes to the school system over the past decade whereas in the United States of America this development began in the 1990s. In most of the countries represented in this special issue of the Journal for Educational Research Online, extracurricular enrichment is off ered in schools in the form of after-school activities. Extracurricular activities take place on a regular basis and are supervised by adults. They include academic activities such as remedial courses and nonacademic activities such as sports, theatre, and gardening. In addition, community programs are off ered at schools by youth organizations 
such as scouts. Typically, all these activities do not adhere to a curriculum and performance is not graded (Fischer, Radisch and Schüpbach, 2014).

Roorda, Koomen, Spilt and Oort used a meta-analytic approach to investigate the associations between affective qualities of teacher-student relationships (TSRs) and students' school engagement and achievement. Results were based on 99 studies, including students from preschool to high school. Separate analyses were conducted for positive relationships and engagement ( $k=61$ studies, $N=88,417$ students), negative relationships and engagement $(k=18, N=5,847)$, positive relationships and achievement $(k=61, N=52,718)$, and negative relationships and achievement $(k=28, N=18,944)$. Overall, associations of both positive and negative relationships with engagement were medium to large, whereas associations with achievement were small to medium. Some of these associations were weaker, but still statistically significant, after correction for methodological biases. Overall, stronger effects were found in the higher grades. Nevertheless, the effects of negative relationships were stronger in primary than in secondary school (Roorda, Koomen, Spilt and Oort, 2011).

Several review articles also have examined the connections between physical activity and academic behavior and achievement. Sibley and Etnier conducted a meta-analysis of published studies relating physical activity and cognition in youth. Two additional reviews described the evidence for relationships between physical activity, brain physiology, cognition, emotion, and academic achievement among children, drawing from studies of humans and other animals across the lifespan. Finally, two other reviews summarized select peer-reviewed research on the relationship between physical activity and academic performance, with an emphasis on school settings and policies. Research also has explored the relationships among physical education and physical activity, fitness levels and motor skill development, and academic performance. For example, several studies have shown a positive relationship between increased physical fitness levels and academic achievement as well as fitness levels and measures of cognitive skills and attitudes. In addition, other studies have shown that improved motor skill levels are positively related to improvements in academic achievement and measures of cognitive skills and attitudes (Rasberry et al, 2011).

\section{MATERIALS AND METHODS}

In this research the descriptive and analytical method is used, where analysis of the current state, comparation and generalization are employed. The technique implemented in the research is enquiry using evaluation scale. According to this technique, a questionnaire was created that uses a scale for evaluating extracurricular activities, for both students and teachers.

The main hypothesis is the assumption that there are different interests for including students and teachers in the process of extracurricular activities.

In this research there is one main and ten auxiliary hypotheses, which doesn't mean the importance of the latter is less, but that they complement the main hypothesis. For this research, four primary schools (three urban and one rural) on the territory of the $\mathrm{Mu}-$ nicipalities of Tetovo and Brvenica were selected: OU "Bratstvo - Migeni", Tetovo; OU "Kiril i Metodij", Tetovo; OU "Lirija", Tetovo; and OU "Kosta Racin", Brvenica. The enquiry covered students of the age between 12 and 15 years, and teachers. The total number of examinees was 248 (184 students and 64 teachers).

The research comprised two questionnaires, one for students and one for teachers.

\section{RESULTS}

Question 1: In what extent you think extra curricular activities are in the function of developing your knowledge and skills?

Table 1. Results of statistical analysis of question 1 .

\begin{tabular}{lrrr}
\hline & $\begin{array}{c}\text { Frequency } \\
\text { (f) }\end{array}$ & $\begin{array}{r}\text { Percentage } \\
\%\end{array}$ & Cumulative \\
\hline A lot & 88 & 47.83 & 47.83 \\
\hline Partially & 85 & 46.20 & 94.02 \\
\hline At all & 11 & 5.98 & 100.00 \\
\hline In total & 184 & 100.00 & \\
\hline
\end{tabular}

H5 - The students are in sufficient extent enabled to satisfy their needs and interests and to develop their individual abilities and preferences.

H5.

Table 2. Results of statistical analysis of

\begin{tabular}{cccccc}
\hline Observation & $\begin{array}{c}\text { Arithmetic } \\
\text { mean }\end{array}$ & $\begin{array}{c}\text { Standard } \\
\text { deviation }\end{array}$ & Min & Max & $\mathrm{x}^{2}$ test \\
\hline 184 & 1.581522 & .6040717 & 1 & 3 & 62.033 \\
\hline
\end{tabular}


The hypothesis can be examined through Question 1 for the students (In what extent you think extracurricular activities are in the function of developing your knowledge and skills?), and from the results obtained it is obvious that a large percentage of the students $(47.83 \%)$ answered "a lot", i.e. they can satisfy their needs and interests and develop their individual abilities and preferences, which way the hypothesis can be considered acceptable.

Question 2: In what extent you think the work of the teachers in the curriculum differs from that in the extracurricular activities?

Table 3. Results of statistical analysis of question 2.

\begin{tabular}{lccc}
\hline & $\begin{array}{c}\text { Frequency } \\
\text { (f) }\end{array}$ & $\begin{array}{c}\text { Percentage } \\
\%\end{array}$ & Cumulative \\
\hline A lot & 55 & 30.22 & 30.22 \\
\hline Partially & 79 & 43.41 & 73.63 \\
\hline At all & 48 & 26.37 & 100.00 \\
\hline In total & 182 & 100.00 & \\
\hline
\end{tabular}

H1 - The students think there is difference in the work of their teachers and in their attitude towards the students in the curriculum and in extracurricular activities.

Table 4. Results of statistical analysis of H1.

\begin{tabular}{cccccc}
\hline Observation & $\begin{array}{c}\text { Arithmetic } \\
\text { mean }\end{array}$ & $\begin{array}{c}\text { Standard } \\
\text { deviation }\end{array}$ & Min & Max & $\begin{array}{c}\mathrm{X}^{2} \\
\text { test }\end{array}$ \\
\hline 182 & 1.961538 & .7533746 & 1 & 3 & 8.714 \\
\hline
\end{tabular}

The hypothesis can also be examined through Question 2 for the students (In what extent you think the work of the teachers in the curriculum differs from that in the extracurricular activities?), and from the results obtained it is obvious that the largest percentage of the students $(43.41 \%)$ and a quite large percentage $(30.22 \%)$ think there is difference between their teachers' work and attitude towards them in the curriculum and in the extracurricular activities, which way the hypothesis cannot be considered completely acceptable. This is so for the reason that there is some difference between teachers' work and attitude towards students in the curriculum and in the extracurricular activities.

\section{DISCUSSION}

Among the scientific public, since long ago there has been an interest in studying free time in general, and especially in studying free time from pedagogical aspect.

The actuality of the subject of investigation is a first degree basis of this topic and the main key to it is always the useful usage of extracurricular activities of students and teachers in the process of primary education; for that reason, as a contradiction there are always present the problems occurring as a consequence of inappropriate use of extracurricular activities. Large number of cases of deviant and delinquent behaviour happen because of boredom, incapability of the individuals to creatively fulfill their free time, and then in these persons a frustration appears regarding their creative potential, which way the individuals become destructive persons.

A large number of youngsters socialize with their alike, i.e. with those who have similar systems of values, orientations, economic status and interests. Instead of building themselves as successful persons, they set on the road to destruction. The influence of the so-called functional education is of dominant importance when it comes to young people's education regarding their free time. This is our reality which is more and more present in free time, for which we ought to prepare the children, to make them resistant and capable of making choices by themselves regarding negative influences, which are anyway enough and against which we cannot fight only by using "morals".

Students' extracurricular activities in school, managed by experienced teachers, can help the young people to build their own attitudes and behaviour, enabling them a positive development and socially acceptable conduct.

The appearance of free time is a product of the modern society and is very closely related to the pace of technical and technological development, and this way it is an issue which still belongs in the sphere of theoretical research. That's why every society, in every period of time, has conceived extracurricular activity programmes, in order to suppress socially pathological behaviour of young people. Certain investigations have shown that teachers, through their work in the process of extracurricular activities, can have a significant role in building and improving students' talents.

\section{CONCLUSIONS}

When education and extracurricular activities are understood in their complementarity and their specific relations are accepted, then they both create perspectives for options. Both of them, through their action, cover the person's entire growth throughout his/her life, and they both include the experience of learning and living into the realization of human potentials. The school has still the best position and the hope 
for developing skills in the students for the wide world of extracurricular activities. That's why we can direct our suggestions into redesigning the structure of schooling programs, and we ought to enable students' initiative and cooperation.

For this reason the teachers ought to support more the freedom in the educational process as well as the feeling of satisfaction by that. Only then the school can become a preoperational step for free activities in the full meaning of the word.

Pedagogical science treats leisure time as an important factor for the realization of the goals of education, but at the same time as a factor of education of the person for cultural and valuable spending the free time. With the very engagement of the students in extracurricular activities satisfaction of their interests is enabled, in the same time positively influencing the complete development of their personality. Also, socially acceptable values are formed, which will further contribute to the development of every modern society.

\section{ACKNOWLEDGMENTS}

We would like to thank our colleges for valuable feedback and making sure we was true to our research.

Thanks are also due to Dr. Marija Kostova and Dr. Aneta Barakoska, who were mentors in our study.

We would like to thank to the research participants - all students: thank you for your participation, for without it, this research would not have been possible.

\section{Conflict of interests}

The authors declare no conflict of interest.

\section{REFERENCES}

Barakoska, A. (2005). Pedagogija na slobodnoto vreme. Filozofski fakultet, Skopje.

Budimir-Ninković, G. (2008). Hrestomatija slobodnog vremena, Pedagoški fakultet, Jagodina.

Corbett, E. P. (1984). Essays on classical rhetoric and modern discourse. R. J. Connors, L. S. Ede, \& A. A. Lunsford (Eds.). SIU Press.

Dumazedier, J. (1963). Vers une civilisation du loisir? Editions du Seul. Paris.

Fischer, N., Radisch, F., \& Schüpbach, M. (2014). International perspectives on extracurricular activities: Conditions of effects on student development, communities and schools-Editorial.
Journal for educational research online, 6(3), 5-9.

Marković, M. (1997). Kultura slobodnog vremena dece i omladine, Zbornik radova, Viša škola za obra $\neg$ zovanje vaspitača, Šabac.

Plenković, J., \& Zalokar, J. (2000). Slobodno vrijeme mladeži. Društvo prijatelja Hrvatska-Japan.

Rasberry, C. N., Lee, S. M., Robin, L., Laris, B. A., Russell, L. A., Coyle, K. K., \& Nihiser, A. J. (2011). The association between school-based physical activity, including physical education, and academic performance: a systematic review of the literature. Preventive medicine, 52, S10-S20.

Roorda, D. L., Koomen, H. M., Spilt, J. L., \& Oort, F. J. (2011). The influence of affective teacherstudent relationships on students' school engagement and achievement a meta-analytic approach. Review of Educational Research, 81(4), 493-529.

Woodfin R., Groves, J. (2003). Aristotel za početnike, Zagreb: Naklada Jesenski i Turk. 